\title{
Mák Kornél
}

\section{SÉMÁK ÉS ÚJÍTÁSOK: A KULTÚRA FINANSZÍROZÁSI HELYZETE A 21. SZÁZAD ELEJI MAGYARORSZÁGON I. (2000-2010)}

\section{Absztrakt}

A finanszírozás kérdése az emberi kultúra létezése óta mindig felmerülő kérdés, a kultúra sosem létezett mecénás támogatása nélkül. Tanulmányomban a kulturális javak gazdasági jellemzőin és a kultúrpolitika sajátosságain keresztül vizsgálom a hazai kultúrafinanszírozás alakulását a 2000-es évektől kezdődően. Ha a magánszektor kulturális támogatásának állami támogatáshoz viszonyított arányát tekintjük, akkor Magyarország európai szinten a GDP 3,9\%-kával a középmezőnyben van. A háztartások kulturális és szabadidős kiadásai 4,30\%-ot tesznek ki, a közvetlen állami támogatás 1,60\%, így hazánkban az állam és a háztartások kulturális kiadásai összesen 5,90\%-os mértékűek A tanulmányban fentiek mellett bemutatásra kerül az önkormányzatok szerepe a kultúra anyagi hátterének biztosításában. A cikk befejezéseként foglalkozom az adórendszer szerepével, illetve a témakör foglalkoztatáspolitikai összefüggéseivel. Kapott eredményeim összegzéseként elmondható, hogy Magyarország 21. századi kultúrafinanszírozása sok tekintetben kiemelkedő az Európai Unió országai közül, de egyfajta útkeresésben van, és a rendszerváltás óta eltelt húsz év még kevés volt arra, hogy a finanszírozás rendszere kellőképpen kialakuljon. Vizsgálatom első részének gyakorlati mondanivalójaként kiemelhető, hogy a bemutatott finanszírozási tendenciák fényében kialakíthatónak tűnik egy hosszú távon is fenntartható finanszírozási rendszer, amely jól szolgálja a kulturális szféra működési stabilitását.

Kulcsszavak: kultúra; finanszírozási modellek; Magyarország

„Amikor a bankárok összejönnek a müvészetről beszélgetnek. Amikor a müvészek összejönnek, a pénzröl beszélgetnek." Oscar Wilde

\section{Bevezetés}

A kultúra finanszírozásának a kérdése mindig is nagyon érdekes terület volt, hiszen, ez amióta csak kultúra létezik, mindig felmerül. A kultúra sosem létezett mecénás támogatása nélkül, és ez napjainkra is igaz. Véleményem szerint a kultúra finanszírozása kötelező feladat kellene, hogy legyen az állam részéről, de ezzel a véleményemmel a szakpolitikában elég éles vitákat váltottam ki. Hasonló kérdés ez, mint a művelődés és kultúrában dolgozók bérének rendezése, ugyanúgy, mint más ágazatokban megvalósult (pl. pedagógusok). Ennek az alapjai, talán már kezdenek kialakulni. 
Először is, vizsgáljuk meg, hogy mi is a kultúra fogalma. Erre a szakirodalom közel 150 különböző definíciót ismer. „A kultúra szó a latin colere (művelni) szóból származik és eredetileg a föld megművelését jelentette.... A kultúra kifejezést ma több eltérő értelemben használjuk, melyek közül a tudományos (antropológiai) és a hétköznapibb magas kultúra értelmezés a leggyakoribb." (Tóth, 2015)

Stark Antal a kultúra gazdasági és társadalmi szerepét, illetve az állami szerepvállalás fontosságát a következőkben határozza meg: „A kultúra intellektuális élményt nyújtó tevékenység, ami nemesíti az embert. A kulturális tevékenység ágazatokba sorolható, lehet egyéni vagy kollektív, szellemi, vagy tárgyiasult. A kultúra, nem csak az egyénnek szerez örömet, hanem komoly társadalmi hasznossága van, mely egyrészt hat az egyének cselekvéseinek színvonalára, a társadalmi együttélésre, végső soron a gazdasági és társadalmi fejlődésre. Ezért az államnak érdeke és kötelessége a kultúra közvetlen (anyagi) vagy közvetett (intézményi) támogatása." (Stark, 2008. p. 52)

\section{A kulturális javak gazdasági sajátosságai, a kultúrpolitika}

Vannak olyan példák (köztéri kőszobrok, belépődíj nélkül látogatható múzeumok és színházi előadások), melyek fogyasztása mindenki számára ingyenes. A művészi tevékenység eredményeként létrejövő jószágok információt hordoznak, így információs javaknak is tekinthetjük őket. A fogyasztás során kulturális élményben részesül a fogyasztó, ennek eredménye, hogy sok más jószágtól megkülönbözteti a kulturális javakat. A kulturális javak olyan sajátos gazdasági tulajdonságokkal rendelkeznek, melyek lehetővé teszik, hogy magát a kulturális szektort közgazdasági szempontból nézzük. Ezek fogyasztása más gazdasági ágazatokra is kihat. Ilyenek a design, építészet, vizuális művészet, előadó művészet, zeneipar, film és audiovizuális ágazat, televízió, rádió, reklámipar, nyomtatott sajtó, turizmus, stb.

A kultúrafinanszírozás a kultúrpolitika egy speciális területét jelenti. A II. világháború óta jelentősen megváltozott a kultúrpolitika cél- és eszközrendszere is.

\section{Kultúrafinanszírozási formák}

$\mathrm{Az}$ állam az egyik kultúrafinanszírozási szereplő. „Az államtól származó támogatások pozitívuma, hogy kiszámíthatóvá teszi a kulturális intézmények működését és a művészeti projektek megvalósíthatóságát. Hátránya, hogy egy idő után a támogatást a kulturális szféra szereplői automatikusnak veszik, így megjelenhet a potyautas-jelenség, csökkenhet a művészi teljesítmény és a gazdasági értelemben vett hatékonyság." (Tóth, 2011, p. 335) A közvetett állami támogatás elsősorban az adókedvezmények, a közvetlen támogatás (normatív), valamint a pályázati források útján ad lehetőséget. Az állami támogatás mellett létezik piaci alapú támogatás és a harmadik szektor támogatása (ajándékozás, közösségi javak, stb.)

A kulturális intézmények állami támogatási rendszerének fő területei a következőek:

- tárgy szerinti csoportosítás: intézményre, személyre, közösségre bontva. 
- Időbeliség alapján a támogatások lehetnek megelőlegezettek vagy utólagosak.

- Időtartam szerint rövid-, közép- és hosszútávúak,

- viszonyítási alap szerint bázisalapúak, normatívak és nullbázisúak,

- konkrétság alapján meghatározottak,

- természetük alapján pénzbeliek és természetbeliek,

- elszámolás alapján folyamatosan, illetve utólag elszámolandók vagy el nem számolandók.

A támogatók között meg kell említeni a civil szervezeteket, alapítványokat, közalapítványokat is. Szintén fontos terület a szponzoráció. Itt jól meghatározható a támogatás fogalma: „Valamilyen független pénzügyi vagy anyagi támogatás, amely nem függ szorosan össze a támogató vállalat kereskedelmi céljaival. A jótékony célú adakozásnak vagy patronálásnak nem célja a haszonszerzés." (Nemzetközi Reklámszövetség, 1988, idézi Fazekas\& Nagy, 2000, p.18)

Az állam beavatkozásának mértéke is fontos. Tanzi szerint a GDP 30\%-át kell az államnak különféle intervenciós folyamatokra fordítania (Tanzi, 2005). Ez akkor igaz, ha minél hatékonyabban múködik a piac, annál kisebb államra van szükség. A kultúra mindenki számára elérhetővé tételében az államnak a magánszektort is be kell vonnia a támogatásba. Ha a magánszektor kulturális támogatásának állami támogatáshoz viszonyított arányát tekintjük, akkor Magyarország európai szinten 3, 9\%-val a középső mezőnyben van (Klamer et al., 2006). Ha azt nézzük meg, hogy a kultúra fogyasztásában hol áll Magyarország, akkor megállapíthatjuk, hogy 11. helyével szintén a középmezőnyben. A háztartások kulturális és szabadidős kiadásai 4,30\%, a közvetlen állami támogatás kultúrára és szabadidős tevékenységekre a GDP \%-ában 1,60\%, az állam és a háztartások kulturális kiadásai így hazánkban összesen: 5,90\% (KEA, 2006).

\section{Magyarország kormányzati kiadása kultúrára}

Posztszocialista országként a támogatási rendszer kialakulása a rendszerváltás után indult el. Megjelentek a nonprofit szervezetek, létrehozták az Angol Művészeti Tanács mintájára a Nemzeti Kulturális Alapot. Fiskális szinten pedig fokozatosan decentralizálták a forráselosztást. A 2000-es évektől kezdődően a politikai döntéshozási mechanizmus azonban egyre erősebben központosított lett. A támogatott területek között megtalálhatjuk a hagyományos kulturális területek mellett a hitélet és a pártok támogatását is, ez más országokban nem része a támogatásnak, valamint támogatott a sport és a szabadidő is.

Magyarország 2011. évi kulturális kiadásainak összege összesen: 396.616 millió forint volt. Ebből sport és szabadidőre 67.798, kulturális tevékenységre 185.800, műsorszórásra, kiadói tevékenységre 75 millió forint lett fordítva (Magyarország Kormánya, 2011). A közvetlen állami támogatás a kulturális kiadásokra 196.650 millió forint volt (KSH, 2011). 
Tehát a kulturális szektoron belül a közművelődés, azon belül a múzeumok és a levéltárak támogatása a legmagasabb, de a három alterület (művelődési központok és művelődési házak, könyvtárak, múzeumok és levéltárak) közel azonos arányban osztozik a támogatásokon. A művészi tevékenységek közül a színházak állami dotációja még a múzeumok és a levéltárak támogatását is meghaladja. A könyv és lapkiadás, valamint a rádió- és televízi-műsorszolgáltatás területek alacsony állami finanszírozása nem meglepő, hiszen ezeken a területeken történt meg először a piaci liberalizáció a magyar kulturális szektorban. Az Európa Unió tagállamainak az állam és a piac kultúrafinanszírozásban betöltött szerepe alapján hazánk a 14., ebben is a középmezőnyben vagyunk.

\section{Hazánk kultúrafinanszírozásának jellemzői}

A magyar kultúrafinanszírozásban a közvetlen állami szerepvállalás a legmeghatározóbb forma. Az Európa Unió tagállamai közül a GDP-arányos közvetlen állami támogatás mértékét tekintve Magyarország az egyik legmagasabb értékkel rendelkezik. Ez 2004-ben a legmagasabb volt az EU-ban 1,6 \%-os szintjével, és azt követő években is az első háromba tartozott (OECD, 2009). A magas aktív állami szerepvállalást igazolja, hogy 2010-ben a 28154 milliárd forint bruttó hazai termékből 333,4 milliárd forint volt a művészet, szórakozás és a szabadidő államháztartási támogatása. (1,2\%) A művészet, a szórakozás, és a szabadidő területei 294,2 milliárd forinttal (1,04\%) járultak hozzá a GDP-hez (KSH, 2010). A kulturális tárca költségvetése 1991 és 2006 között folyamatosan növekedett, majd erőteljes visszaesés következett be, mely a 2009-es évben érte el mélypontját. A 2008-as gazdasági válság erősen éreztette hatását a kulturális finanszírozásban. A központi költségvetés kultúrára fordított forrása 2008-ról 2009-re 30\%-ra esett vissza. Mindezek nyomán 2010-ben az 1991-es szintre állt vissza a kultúrára fordított közvetlen állami támogatás mértéke. A GDP-arányos támogatás 2007-re közel azonos szintre állt be, mint ami 1989-ben volt jellemző.

Érdekes kérdés, hogy ahogyan az állami szerepvállalás növekedett a kultúrafogyasztás tekintetében, hogyan alakult ez a lakosság körében? A háztartások kulturális kiadása az összkiadáshoz viszonyítva Magyarországon 4,7 százalék, ami az uniós 3,9 százaléknál magasabb. Számszerűsítve viszont csak a fele az uniós átlagnak, mivel Magyarországon 493 eurót, míg az Unió 27 tagállamában átlagosan 888 eurót költenek éves szinten kultúrára. A televízió- és rádiószolgáltatások kiadásai nálunk magasak (30,8\%). Ez nem meglepő, hiszen a magyar lakosság rendkívül sokat, naponta átlagosan 4 órát néz televíziót. A film-, színház-, és koncertkiadások hazánkban (5,3\%) az uniós átlag $(7,1 \%)$ alatt vannak. A kultúrára fordított közvetlen ellátás rendszere Magyarországon függ a gazdaság pillanatnyi helyzetétől, a forráselosztás szempontjából, egyfajta útkeresés jellemző. A források csökkenése ellenére 1991-hez képest 2010-ben, ha nem is sokkal, de többet költött az állam kultúrára. Vagyis több, mint két évtizeddel a rendszerváltást követően a magyar kultúrafinanszírozásban az állam még mindig meghatározó szerepet tölt be (Tóth, 2013). 


\section{Az önkormányzatok szerepe a kultúrafinanszírozásban, szponzoráció}

A központi költségvetésből a helyi önkormányzatok számára nyújtott központi támogatás mértéke folyamatosan nőtt 2001 és 2007 között, 2008-ra figyelhető meg enyhe csökkenés az önkormányzatoknak szánt támogatásokban. Nemcsak az állami szerepvállalás nőtt, de annak helyi önkormányzatok felé történő átcsoportosítása is egyre hangsúlyosabb szerepet kapott. A helyi önkormányzatok közül csak a nagyobb települések képesek arra, hogy a kultúra támogatására saját költségvetésből adjanak összegeket. A pályázati forma (Nemzeti Kulturális Alap, miniszteri keret) felé való pályázat inkább a jellemző. Fontos, hogy egy település hogyan tudja összekapcsolni kulturális lehetőségeit a helyi adottságokkal, amivel bevételt is lehet teremteni. (pl. turizmus).

A nyugati, elsősorban liberális kultúrafinanszírozási gyakorlat egyik legismertebb támogatási formája a szponzoráció. Magyarországon és a többi posztszocialista ország esetében ez a támogatási forma robbanásszerűen alakult ki a nonprofit szektorral együtt. Hazánkban a magánszektorból való állami támogatás arányában 3,9\%. A rendszerváltást követően 1993-ban jelentek meg az első nonprofit szervezetek. Számuk 1997-ig erőteljesen nőtt, majd 2000-ig stagnálás, sőt 1999 és 2000 között enyhe csökkenés következett be. 2000-től azonban a nonprofit szervezetek száma dinamikusan emelkedik. A bevételek reálértéke folyamatosan nő. A nonprofit szektor bevételének 43\%-át az állam nyújtja, csökken a magánszféra szerepe, mert a piaci szereplőket az állami szerepvállalás kiszorítja. A központi politikai befolyás erősödése negatívan hat a szektor működésére. Állami bizalmatlanság jelenik meg a szektor iránt, annak átláthatatlansága miatt.

\section{Az adókedvezmények rendszere Magyarországon, a kulturális szféra foglalkoztatáspolitikája}

Az adókedvezményeken keresztül történő kultúrafinanszírozás létezik hazánkban. Erős a kortárs művészeteket támogató kedvezmények rendszere, sajnos nem léteznek a vállalati szponzorációt ösztönző adókedvezményi formák (kivéve kulturális TAO, például színházak esetében).

A legfontosabb adókedvezmények a következők:

- a jövedelemadó 1\%-a feletti rendelkezés,

- 5\%-os áfa a könyvekre,

- 25\%-os áfa hanghordozókra,

- 15\%-os áfa folyóiratokra, belépőjegyekre, filmkészítésre, kézműves termékekre,

- szerzői jogdíjból származó jövedelem utáni adókedvezmény max. 50.000 forintig. 
A kulturális foglalkoztatásnál elmondható, hogy a foglalkoztatottak 2\%-a dolgozik a kulturális szektorban. 2010-ben a művészet, a szabadidő és a szórakozás területein 36.400 főt foglalkoztattak, ebből teljes munkaidőben dolgozott 31.200 fő. A teljes munkaidőben dolgozók havi átlagkeresete 142.282 forint volt (KSH, 2010). Az Uniós átlaghoz viszonyítva Magyarországon magasabb a kulturális szektorban foglalkoztatott nők aránya. A nők 51,7\%-os aránya magasabb a brit és francia adatoknál is. Hazánkban a kulturális intézményekben az a tendencia alakult ki, hogy inkább a nők vannak többségben az alkalmazottak között. A kor szerinti megoszlást vizsgálva azt tapasztaljuk, hogy az uniós átlaghoz képest alacsonyabb a 15-29 év közöttiek, míg magasabb az 50 év felettiek aránya. Végzettség tekintetében a szektorban magas a felsőfokú végzettségűek aránya, viszont a vállalkozói szemlélet alapján munkát vállalók aránya alacsony.

Elmondható, hogy Magyarország 21. századi kultúrafinanszírozása sok tekintetben kiemelkedő az Unió országai közül, de egyfajta útkeresésben van, és a rendszerváltás óta eltelt 20 év még kevés volt arra, hogy a finanszírozás rendszere kellőképpen kialakuljon. Reméljük, hogy jó úton vagyunk efelé.

\section{Irodalomjegyzék}

Fazekas, I. \& Nagy, A. (2000). Szponzorálás. Budapest: Nemzeti Tankönyvkiadó.

KEA (2006). The Economy in Culture in Europe. Luxembourg: European Commission. http://ec.europa.eu/culture/eac/sources/info/studies/economy_en.html.

Letöltés dátuma: 2020.08.23.

Klamer A., Petrova L., \& Mignosa A. (2006). Financing the Arts and Culture in the European Union. Brussels: European Union.

KSH (2010). Magyar statisztikai évkönyv. Budapest: Központi Statisztikai Hivatal.

KSH (2011). Magyar statisztikai évkönyv. Budapest: Központi Statisztikai Hivatal.

Magyarország Kormánya (2011). Az államháztartás konszolidált funkcionális kiadásai (pénzforgalmi szemléletben).

http://www.parlament.hu/irom39/01498/adatok/altindmell/fu_kon.pdf Letöltés dátuma: 2020.09.18.

Stark A. (2008.). Kultúra és finanszírozás. Pénzügyi Szemle, 53 (1), 64-82.

OECD (2009.). Economic, Environmentaland Social Statistics. Paris: OECD.

http://www.oecd-ilibrary.org/economics/oecd-factbook-2009-en,jsessionid=m9cxe302bsaw.x-oecdlive-02 Letöltés dátuma: 2020.08.30.

Tanzi, V. (2005). The Economic Role of the State in the 21st Century. Cato Journal, 25 (3), 617-638.

Tóth, Á. (2011). Az állam kultúrafinanszírozásban betöltött szerepének megváltozása a kultúra demokratizálódásának hatására. Közgazdasági Szemle, 58 (április), 333-350.

Tóth, Á. (2013). Kultúrafinanszírozás az Európai Unió tagállamaiban és Magyarországon. Budapest: Akadémia Kiadó.

Tóth Á. (2015). Kultúrafinanszírozás. Budapest: Akadémiai Kiadó. https://doi.org/10.1556/9789630593403;

https://mersz.hu/hivatkozas/kultura_s1.1_p3\#kultura_s1.1_p3 Letöltés dátuma: 2020.12.29. 